\title{
Mononuclear to Polynuclear Transition Induced by Ligand Coordination: Synthesis, X-ray Structure, and Properties of Mono-, Di-, and Polynuclear Copper(II) Complexes of Pyridyl-Containing Azo Ligands
}

\author{
Srijit Das, ${ }^{\dagger}$ Priyabrata Banerjee, ${ }^{\dagger}$ Shie-Ming Peng, ${ }^{\ddagger}$ Gene-Hsiang Lee, ${ }^{\ddagger}$ Jinkwon Kim,$\$$ and \\ Sreebrata Goswami ${ }^{*}$, \\ Department of Inorganic Chemistry, Indian Association for the Cultivation of Science, \\ Kolkata 700 032, India, Department of Chemistry, National Taiwan University, Taipei, Taiwan, \\ Republic of China, and Department of Chemistry, Kongju National University, 182 Shinkwan, \\ Kongju, Chungnam 314-701, Republic of Korea
}

Received June 23, 2005

\begin{abstract}
Reactions of two hydrated cupric salts $\left(\mathrm{CuCl}_{2} \cdot 2 \mathrm{H}_{2} \mathrm{O}\right.$ and $\left.\mathrm{Cu}\left(\mathrm{ClO}_{4}\right)_{2} \cdot 6 \mathrm{H}_{2} \mathrm{O}\right)$ with three azopyridyl ligands, viz. 2-[(arylamino)phenylazo]pyridine [aryl = phenyl $\left(\mathrm{HL}^{1 \mathrm{1a}}\right)$, p-tolyl $\left(\mathrm{HL}^{1 \mathrm{~b}}\right)$, and 2-thiomethyl phenyl $\left.\left(\mathrm{HL}^{1 \mathrm{c}}\right)\right]$, 2-[2(pyridylamino)phenylazo]pyridine $\left(\mathrm{HL}^{2}\right)$, and 2-[3-(pyridylamino)phenylazo]pyridine $\left(\mathrm{HL}^{3}\right)$, afford the mononuclear [CuClL'] (1), dinuclear $\left[\mathrm{Cu}_{2} \mathrm{X}_{2} \mathrm{~L}_{2}^{2}\right]^{n+}\left(\mathrm{X}=\mathrm{Cl}, \mathrm{H}_{2} \mathrm{O}, \mathrm{ClO}_{4} ; n=0,1 ; 2,3\right)$, and polynuclear $\left[\mathrm{CuClL}^{3}\right]_{n}(4)$ complexes, respectively, in high yields. Representative $X$-ray structures of these complexes 1-4 are reported. X-ray structure analysis of 4 reveals an infinite 1D zigzag chain that adopts a saw-tooth-like structure. Variable-temperature cryomagnetic measurements $(2-300 \mathrm{~K})$ on the complexes $2-4$ have revealed weak magnetic interactions between the copper centers with $J$ values $-1.04,9.88$, and $-1.31 \mathrm{~cm}^{-1}$, respectively. Positive ion ESI mass spectra of the soluble complexes 1-3 are studied which provide the evidence for the integrity of the complexes also in solution. Visible range spectra of the complexes 1-3 in solution consist of intense and broad transitions in the range 700 $600 \mathrm{~nm}$. The solid-state spectrum of the insoluble copper complex 4, on the other hand, shows a structured band near $700 \mathrm{~nm}$. The intensities of the transitions of the dinuclear complexes are much higher than those of the corresponding mononuclear copper complexes. Redox properties of the present copper complexes are reported. Notably, the dinuclear complex, 3 , displays two successive redox processes: $\mathrm{Cu}^{\prime \prime} \mathrm{Cu}{ }^{\prime \prime} \rightleftharpoons \mathrm{Cu}^{\prime \prime} \mathrm{Cu}^{\prime} \rightleftharpoons \mathrm{Cu}{ }^{\prime} \mathrm{Cu}$ '. It catalyzes aerial oxidation of L-ascorbic acid. The catalytic cycle is most effective up to $\mathrm{H}_{2} \mathrm{~A} / 3\left(\mathrm{H}_{2} \mathrm{~A}=\mathrm{L}\right.$-ascorbic acid) molar ratio of 20:1.
\end{abstract}

\section{Introduction}

Azoaromatic compounds have been known to have wide application $^{1,2}$ in the dyestuff industry and also more recently in the field of optical data storage and nonlinear optics. However, examples of well-characterized azo-based di- and polynuclear systems are limited in the literature primarily due to lack of availability ${ }^{3}$ of suitable bridging ligands. Therefore, there is an obvious need to develop syntheses of

* To whom correspondence should be addressed. E-mail:icsg@ iacs.res.in. Fax: +913324732805.

$\dagger$ Indian Association for the Cultivation of Science.

$\ddagger$ National Taiwan University.

$\S$ Kongju National University. azo-based ligands that are suitable for the construction of polynuclear frameworks.

(1) (a) Bach, H.; Anderle, K.; Fuhrmann, Th.; Wendorff, J. H. J. Phys. Chem. 1996, 100, 17337. (b) Taniike, K.; Matsumoto, T.; Sato, T.; Ozaki, Y.; Nakashima, K.; Iriyama, K. J. Phys. Chem. 1996, 100, 15508 (c) Clark, R. J. H.; Hester, R. E. Advances in Material Science Spectroscopy; Wiley: New York, 1991. (d) Rou, H. Photochromism. Molecules and Systems; Durr, H., Bouaslourent, H., Eds.; Elsevier: Amsterdam, 1990; Chapter 4, p 165. (e) Zollinger, H. Color Chemistry, Syntheses, Properties and Applications of Organic Dyes and Pigments; VCH: New York, 1987; p 92.

(2) (a) Willner, I.; Rubin, S. Angew. Chem., Int. Ed. Engl. 1996, 35, 367. (b) Ramanujam, P. S.; Hvilsted, S.; Zebger, I.; Siesler, H. W. Macromol. Rapid Commun. 1995, 16, 455. (c) Lee, G. J.; Kim. D.; Lee, M. Appl. Opt. 1995, 34, 138. (d) Ramanujam, P. S.; Hvilsted, S.; Andruzzi, F. Appl. Phys. Lett. 1993, 62, 1041. (e) Hvilsted, S.; Andruzzi, F. Ramanujam, P. S. Opt. Lett. 1992, 17, 1234.

10.1021/ic051029c CCC: $\$ 33.50$ (c) 2006 American Chemical Society Published on Web 12/16/2005 


\section{Scheme 1}

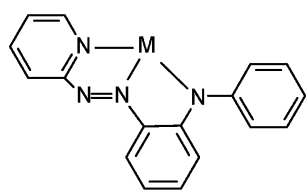

mononuclear

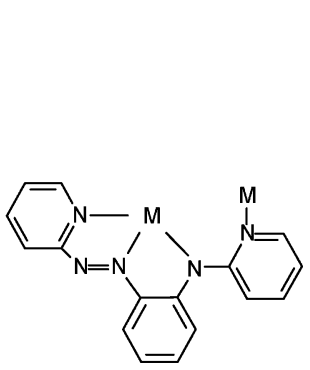

dinuclear
[

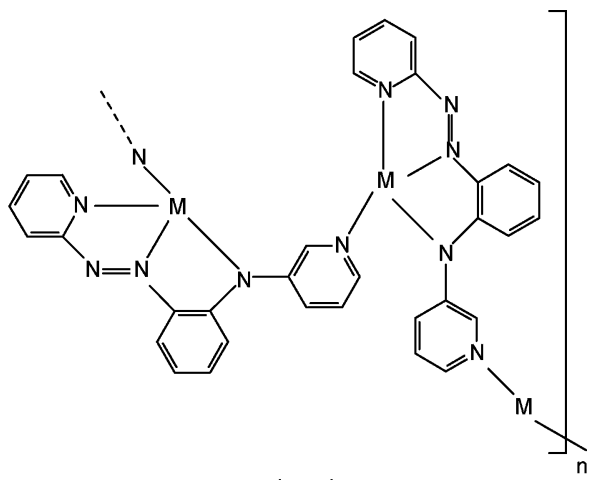

polynuclear
During recent years we have been working on the designed synthesis ${ }^{4}$ of a new class of azo-containing polydentate ligands. A tridentate ligand, 2-[(arylamino)phenylazo]pyridine $\left(\mathrm{HL}^{1}\right)$, was first isolated via regioselective ortho-fusion of primary aromatic amines on cobalt(II)-coordinated 2-(phenylazo)pyridine (pap). The coordination chemistry of this bis-chelating ligand has some unique features. For example, it stabilizes uncommon low-spin states ${ }^{5}$ of manganese(II) and iron(II) and also produces complexes of stable azo-radical ions. ${ }^{6}$ The success in this area has persuaded us to develop azo-containing bridging ligands. Accordingly, positional isomers of pyridylamines are chosen as the reagents for the above amine fusion reaction. The ligands used in this work are shown in Chart 1.

Chart 1
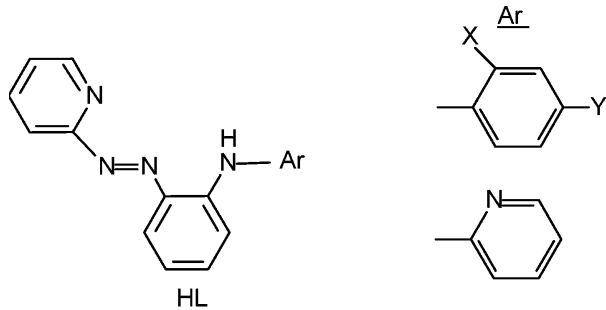

$\underline{\mathrm{HL}}$

$H L^{1}$

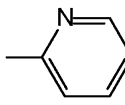

$\mathrm{HL}^{2}$

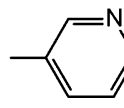

$\mathrm{HL}^{3}$

It was hoped that introduction of a pyridyl function in the place of the phenyl ring would produce the desired bridging ligands. The ability of the 2-aminopyridine functionality to serve as three-atom bridge has long been known, ${ }^{7}$ and thus, the deprotonated ligand $\left[\mathrm{L}^{2}\right]^{-}$primarily forms binuclear ${ }^{8}$

(3) (a) Kaim, W. Coord. Chem. Rev. 2001, 219-221, 463. (b) Hartmann, H.; Scheiring, T.; Fiedler, J.; Kaim, W. J. Organomet. Chem. 2000, 604, 267

(4) Saha, A.; Ghosh, A. K.; Majumdar, P.; Mitra, K. N.; Mondal, S.; Rajak, K. K.; Falvello, L. R.; Goswami, S. Organometallics 1999, 18, 3772.

(5) (a) Saha, A.; Majumdar P.; Goswami, S. J. Chem. Soc., Dalton Trans. 2000, 1703. (b) Saha, A.; Majumdar, P.; Peng, S.-M.; Goswami, S. Eur. J. Inorg. Chem. 2000, 2631.

(6) Sanyal, A.; Banerjee, P.; Lee, G.-H.; Peng, S.-M. Hung, C.-H.; Goswami, S. Inorg. Chem. 2004, 43, 7456.

(7) (a) Chakravarty, A. R.; Cotton F. A.; Falvello, L. R. Inorg. Chem. 1986, 25, 214. (b) Chakravarty, A. R.; Cotton F. A.; Tocher. D. A. Organometallics 1985, 4, 863.

(8) (a) Das, S.; Hung, C.-H.; Goswami, S. Inorg. Chem. 2003, 42, 5153. (b) Kamar, K. K.; Das, S.; Hung, C.-H.; Castiñeiras, A.; Rillo, C.; Kuzmin, M.; Goswami, S. Inorg. Chem. 2003, 42, 5367. (c) Das, S.; Hung, C.-H.; Goswami, S. Inorg. Chem. 2003, 42, 8592. compounds. In contrast, the coordination chemistry of 3 -aminopyridine is unknown and molecular modeling on the coordination mode ${ }^{9}$ of $\left[\mathrm{L}^{3}\right]^{-}$indicates the possibility of formation of coordination polymers (Scheme 1).

In this work we have investigated the coordination chemistry of copper complexes involving the above aromatic amine-substituted aryl azo ligands, $\mathrm{HL}^{1}-\mathrm{HL}^{3}$. There has been an increasing interest in the coordination chemistry of multinuclear systems due to their modified properties ${ }^{10}$ that primarily originate due to the interactions between different metal centers. For similar reasons the chemistry of copper complexes of high nuclearity involving the pyridyl-based ligands are of interest. ${ }^{11}$ Furthermore, we note that structure building and the deliberate design of polynuclear coordination compound ${ }^{12}$ are also important due to their potential as new functional solid materials.

\section{Results and Discussion}

A. Synthesis and X-ray Structures. (i) Mononuclear Copper(II) Complexes. Hydrated $\mathrm{CuCl}_{2} \cdot 2 \mathrm{H}_{2} \mathrm{O}$ reacted almost instantaneously with an equimolar quantity of the deprotonated ligands, $\left[\mathrm{L}^{1}\right]^{-}$, in methanol resulting in molecular complexes of formula $\left[\mathrm{CuClL}^{1}\right]$ (1) in high yields $(>80 \%)$. There was distinct color change from red (free $\left.\left[\mathrm{L}^{1}\right]^{-}\right)$to green complexes, $\mathbf{1}$. The copper complex $\mathbf{1 c}$ of the substituted ligand, $\left[\mathrm{L}^{1 \mathrm{c}}\right]^{-}$, produced suitable crystals for X-ray diffraction.
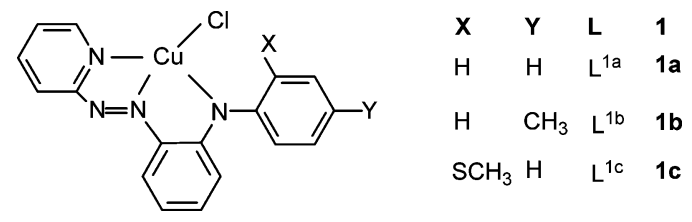

The molecular structure of $\mathbf{1 c}$ is shown in Figure 1, and its selected bond parameters are collected in Table 1. The $\mathrm{Cu}(\mathrm{II})$ ion in this complex is four-coordinate, and the

(9) Banerjee, P.; Lee, G.-H.; Peng, S.-M.; Goswami, S. Manuscript in preparation.

(10) Ambrosi, G.; Formica, M.; Fusi, V.; Giorgi, L.; Guerri, A.; Lucarini, S.; Micheloni, M.; Paoli, P.; Rossi, P.; Zappia, G. Inorg. Chem. 2005, $44,3249$.

(11) Mirica, L. M.; Ottenwaelder, X.; Stack, T. D. P. Chem. Rev. 2004, 104, 1013.

(12) (a) Gao, E.-Q.; Bai, S.-Q.; Wang, C.-F.; Yue, Y.-F.; Yan, C.-H. Inorg. Chem. 2003, 42, 8456. (b) Zaman, M. B.; Smith, M. B.; Ciurtin, D. M.; Zurloye, H.-C. Inorg. Chem. 2002, 41, 4895. 
Das et al.

Table 1. Selected Bond Lengths $(\AA)$ and Angles (deg) for the Complexes 1c and 2-4

\begin{tabular}{|c|c|c|c|c|c|}
\hline \multicolumn{6}{|c|}{ Complex 1c } \\
\hline $\mathrm{Cu}-\mathrm{N}(1)$ & $2.0092(16)$ & $\mathrm{Cu}-\mathrm{N}(3)$ & $1.9603(15)$ & $\mathrm{Cu}-\mathrm{N}(4)$ & $1.9706(16)$ \\
\hline $\mathrm{Cu}-\mathrm{Cl}$ & $2.1965(5)$ & $\mathrm{N}(2)-\mathrm{N}(3)$ & $1.285(2)$ & $\mathrm{N}(3)-\mathrm{C}(6)$ & $1.351(2)$ \\
\hline$C(6)-C(11)$ & $1.436(3)$ & $\mathrm{C}(11)-\mathrm{N}(4)$ & $1.331(2)$ & $\mathrm{N}(4)-\mathrm{C}(12)$ & $1.420(2)$ \\
\hline $\mathrm{N}(1)-\mathrm{Cu}-\mathrm{N}(3)$ & $77.52(6)$ & $\mathrm{N}(3)-\mathrm{Cu}-\mathrm{N}(4)$ & $81.78(6)$ & $\mathrm{N}(4)-\mathrm{Cu}-\mathrm{Cl}$ & $102.07(5)$ \\
\hline $\mathrm{Cl}-\mathrm{Cu}-\mathrm{N}(1)$ & $98.67(5)$ & & & & \\
\hline \multicolumn{6}{|c|}{ Complex 2} \\
\hline $\mathrm{Cu}(1)-\mathrm{N}(1)$ & $2.020(4)$ & $\mathrm{Cu}(1) \mathrm{N}(3)$ & $1.996(3)$ & $\mathrm{Cu}(1)-\mathrm{N}(4)$ & $1.985(3)$ \\
\hline $\mathrm{Cu}(1)-\mathrm{Cl}(1)$ & $2.3947(11)$ & $\mathrm{Cu}(1)-\mathrm{N}(5 \mathrm{~A})$ & $2.108(3)$ & $\mathrm{N}(2)-\mathrm{N}(3)$ & $1.284(5)$ \\
\hline $\mathrm{N}(3)-\mathrm{C}(6)$ & $1.356(5)$ & $C(6)-C(11)$ & $1.434(6)$ & $\mathrm{C}(11)-\mathrm{N}(4)$ & $1.333(5)$ \\
\hline $\mathrm{N}(4)-\mathrm{C}(12)$ & $1.406(5)$ & & & & \\
\hline $\mathrm{N}(1)-\mathrm{Cu}(1)-\mathrm{N}(3)$ & $77.13(15)$ & $\mathrm{N}(3)-\mathrm{Cu}(1)-\mathrm{N}(4)$ & $80.05(15)$ & $\mathrm{N}(4)-\mathrm{Cu}(1)-\mathrm{N}(5 \mathrm{~A})$ & $97.13(13)$ \\
\hline $\mathrm{N}(5 \mathrm{~A})-\mathrm{Cu}(1)-\mathrm{Cl}(1)$ & $98.60(10)$ & & & & \\
\hline \multicolumn{6}{|c|}{ Complex 3} \\
\hline $\mathrm{Cu}(1)-\mathrm{N}(6)$ & $1.996(9)$ & $\mathrm{Cu}(1)-\mathrm{N}(8)$ & $1.966(6)$ & $\mathrm{Cu}(1)-\mathrm{N}(9)$ & $1.946(6)$ \\
\hline $\mathrm{Cu}(1)-\mathrm{N}(5)$ & $2.000(8)$ & $\mathrm{Cu}(1)-\mathrm{O}(1)$ & $2.378(7)$ & $\mathrm{Cu}(2)-\mathrm{N}(1)$ & $1.979(8)$ \\
\hline $\mathrm{Cu}(2)-\mathrm{N}(3)$ & $1.952(6)$ & $\mathrm{Cu}(2)-\mathrm{N}(4)$ & $1.968(6)$ & $\mathrm{Cu}(2)-\mathrm{N}(10)$ & $1.997(8)$ \\
\hline $\mathrm{Cu}(2)-\mathrm{O}(2)$ & $2.465(7)$ & $\mathrm{N}(7)-\mathrm{N}(8)$ & $1.209(10)$ & $\mathrm{N}(8)-\mathrm{C}(22)$ & $1.447(11)$ \\
\hline$C(22)-C(27)$ & $1.417(14)$ & $\mathrm{C}(27)-\mathrm{N}(9)$ & $1.381(12)$ & $\mathrm{N}(9)-\mathrm{C}(28)$ & $1.459(10)$ \\
\hline $\mathrm{N}(2)-\mathrm{N}(3)$ & $1.239(11)$ & $\mathrm{N}(3)-\mathrm{C}(6)$ & $1.431(11)$ & $\mathrm{C}(6)-\mathrm{C}(11)$ & $1.380(15)$ \\
\hline $\mathrm{C}(11)-\mathrm{N}(4)$ & $1.396(12)$ & $\mathrm{N}(4)-\mathrm{C}(12)$ & $1.387(11)$ & & \\
\hline $\mathrm{N}(8)-\mathrm{Cu}(1)-\mathrm{N}(6)$ & $75.9(3)$ & $\mathrm{N}(9)-\mathrm{Cu}(1)-\mathrm{N}(8)$ & $82.4(2)$ & $\mathrm{N}(3)-\mathrm{Cu}(2)-\mathrm{N}(1)$ & $77.1(3)$ \\
\hline $\mathrm{N}(3)-\mathrm{Cu}(2)-\mathrm{N}(4)$ & $83.1(2)$ & & & & \\
\hline \multicolumn{6}{|c|}{ Complex 4} \\
\hline $\mathrm{Cu}(\mathrm{a})-\mathrm{N}(1 \mathrm{a})$ & $2.024(3)$ & $\mathrm{Cu}(\mathrm{a})-\mathrm{N}(3 \mathrm{a})$ & $1.963(3)$ & $\mathrm{Cu}(\mathrm{a})-\mathrm{N}(4 \mathrm{a})$ & $2.029(3)$ \\
\hline $\mathrm{Cu}(\mathrm{a})-\mathrm{Cl}(\mathrm{a})$ & $2.2408(11)$ & $\mathrm{Cu}(\mathrm{a})-\mathrm{N}(5)$ & $2.205(3)$ & $\mathrm{N}(2 \mathrm{a})-\mathrm{N}(3 \mathrm{a})$ & $1.295(4)$ \\
\hline $\mathrm{N}(3 \mathrm{a})-\mathrm{C}(6 \mathrm{a})$ & $1.356(4)$ & $C(6 a)-C(11 a)$ & $1.435(5)$ & $\mathrm{C}(11 \mathrm{a})-\mathrm{N}(4 a)$ & $1.329(4)$ \\
\hline$N(4 a)-C(12 a)$ & $1.411(4)$ & & & & \\
\hline $\mathrm{N}(1 \mathrm{a})-\mathrm{Cu}(\mathrm{a})-\mathrm{N}(3 \mathrm{a})$ & $77.23(12)$ & $\mathrm{N}(3 \mathrm{a})-\mathrm{Cu}(\mathrm{a})-\mathrm{N}(4 \mathrm{a})$ & $80.18(12)$ & $\mathrm{N}(4 \mathrm{a})-\mathrm{Cu}(\mathrm{a})-\mathrm{Cl}(\mathrm{a})$ & $102.85(9)$ \\
\hline $\mathrm{Cl}(\mathrm{a})-\mathrm{Cu}(\mathrm{a})-\mathrm{N}(5)$ & $102.15(9)$ & & & & \\
\hline
\end{tabular}

geometry around it is a distorted square planar. The metal atom is located $0.0272(3) \AA$ above the mean basal plane formed by the coordinating atoms, viz. $\mathrm{N}(1), \mathrm{N}(3), \mathrm{N}(4)$, and $\mathrm{Cl}$. Deviation from the idealized square geometry is due to geometric constraints imposed by the tridentate ligand. The $\mathrm{Cu}-\mathrm{N}$ lengths showed expected variation with that to the middle nitrogen $(\mathrm{N}(3))$ being shorter than those to the other two terminal nitrogen atoms, viz. N(1) and N(4). The chelate bite angles are in agreement with those of the previously reported ${ }^{4}$ complexes of $\left[\mathrm{L}^{1}\right]^{-}$. Crystal packing of complex 1c reveals an array of intra- and intermolecular $\mathrm{C}-\mathrm{H} \cdots \mathrm{Cl}$ hydrogen-bonding interactions (Figure S1). Two distinct types of $\mathrm{C}-\mathrm{H} \cdots \cdot \mathrm{Cl}$ interactions ${ }^{13}$ are present between the acceptors, i.e., the metal bound chloride ion and the $\mathrm{C}-\mathrm{H}$ moieties (donors) on the same or an adjacent molecule. The identified donors are the $\mathrm{H}(1)$ atom of a pyridine ring (intramolecular donor in nature) and $\mathrm{H}(3)$ atom of the

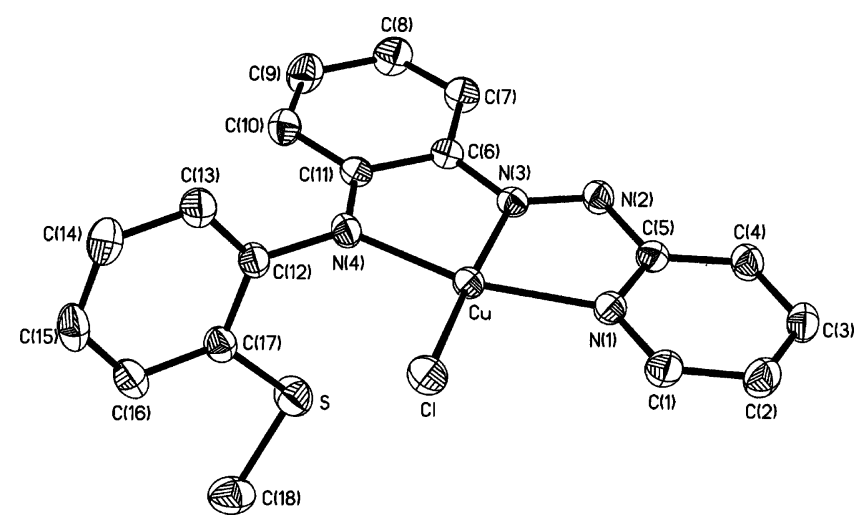

Figure 1. ORTEP and atom-numbering scheme for $\left[\mathrm{CuCl}\left(\mathrm{L}^{1 \mathrm{c}}\right)\right](\mathbf{1 c})$. Hydrogen atoms are omitted for clarity. pyridine ring of an adjacent molecule (intermolecular donor in nature). The intra- and intermolecular distances are 2.8465(6) and 2.8600(5) $\AA$, respectively. These distances are appreciably shorter than the sum of the van der Waals radii for the hydrogen and the neutral chlorine atoms $(2.95 \AA)$. These noncovalent interactions have led to a 1D sinusoidal architecture along the $a$ axis.

(ii) Dinuclear Copper(II) Complexes. (a) $\left[\mathrm{Cu}_{2} \mathrm{Cl}_{2} \mathrm{~L}^{2}{ }_{2}\right.$. $\mathrm{H}_{2} \mathrm{O}$ (2). The reaction of hydrated salt $\mathrm{CuCl}_{2} \cdot 2 \mathrm{H}_{2} \mathrm{O}$ with an equimolar quantity of the deprotonated $\left[\mathrm{L}^{2}\right]^{-}$in methanol produced a sky-blue solution from which a molecular dicopper complex, $\left[\mathrm{Cu}_{2} \mathrm{Cl}_{2} \mathrm{~L}_{2}^{2}\right] \cdot \mathrm{H}_{2} \mathrm{O}(\mathbf{2})$, was obtained in a high yield (75\%). The X-ray structure of the complex $\mathbf{2}$ is shown in Figure 2, and its bond parameters are collected in Table 1. The complex $\mathbf{2}$ is located at the crystallographic 2 -fold axis; only half of it occupies the asymmetric unit. Each copper atom in this molecule is in a pentacoordinated $\mathrm{N}_{4} \mathrm{Cl}$ environment. The three coordinating nitrogen atoms, viz. $\mathrm{N}(1), \mathrm{N}(3)$, and the deprotonated secondary amine $\mathrm{N}(4)$, of one $\left[\mathrm{L}^{2}\right]^{-}$bind to $\mathrm{Cu}(1)$ as a bis-chelating tridentate ligand while the second pyridyl nitrogen $\mathrm{N}(5)$ bridges $^{8 \mathrm{a}}$ to another $\mathrm{Cu}(1 \mathrm{~A})$ atom. Tridentate coordination of one $\left[\mathrm{L}^{2}\right]^{-}$and pyridyl nitrogen of a second $\left[\mathrm{L}^{2}\right]^{-}$ligand, together with one chloride, thus completes five-coordination about each copper. The three coordinating nitrogen atoms, viz. $\mathrm{N}(1), \mathrm{N}(3)$, and $\mathrm{N}(4)$, form a good plane, and $\mathrm{Cu}(1)$ sits above this plane by $0.0500(4) \AA$. The geometry around each $\mathrm{Cu}$ atom is highly distorted; the angular structural parameter ${ }^{14} \tau$, value equals 0.55 suggesting more likely a trigonal bipyramidal structure.

(13) (a) Balamurugan, V.; Hundal, M. S.; Mukherjee, R. Chem.-Eur. J. 2004, 1683. (b) Aakeröy, C. B.; Evans, T. A.; Seddon, K. R.; Pálinkó, I. New J. Chem. 1999, 145.

564 Inorganic Chemistry, Vol. 45, №. 2, 2006 


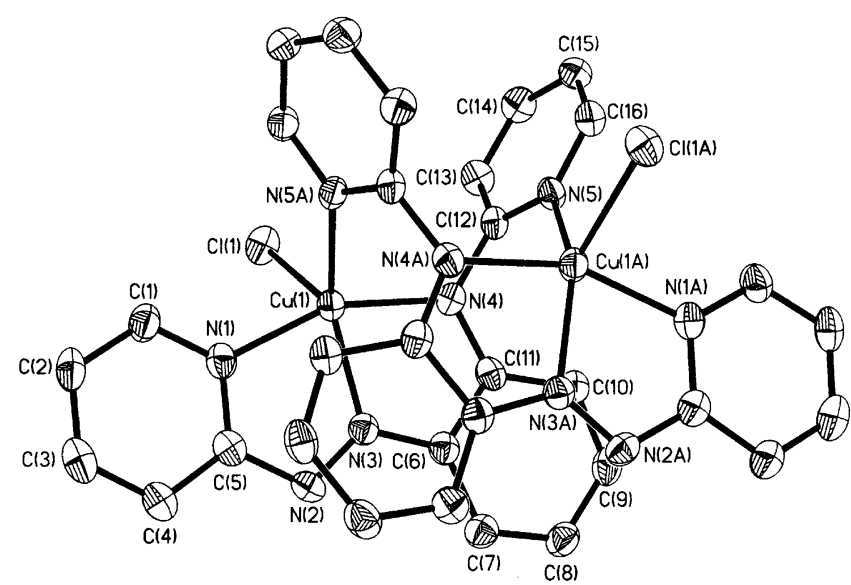

Figure 2. ORTEP and atom-numbering scheme for $\left[\mathrm{Cu}_{2} \mathrm{Cl}_{2} \mathrm{~L}^{2}{ }_{2}\right] \cdot \mathrm{H}_{2} \mathrm{O}(2)$. Hydrogen atoms are omitted for clarity.

The four $\mathrm{Cu}-\mathrm{N}$ lengths along with $\mathrm{Cu}-\mathrm{Cl}$ lengths are normal. Notably, the separation between $\mathrm{Cu}(1) \cdots \mathrm{N}(4 \mathrm{~A})$ is 3.144(4) $\AA$, which is longer than a typical covalent $\mathrm{Cu}-\mathrm{N}$ length, but is shorter than the sum of van der Waals radii ${ }^{15}$ of $\mathrm{Cu}$ and $\mathrm{N}$. The separation between the two copper atoms in the present complex is $4.182 \AA$. Complex 2 also contains one molecule of $\mathrm{H}_{2} \mathrm{O}$ as a solvent of crystallization. In the crystal packing, the dimeric units of the complex $\mathbf{2}$ are connected through an extensive network ${ }^{16}$ of hydrogen bonds. The void volume/unit cell is filled by uncoordinated water molecules. Furthermore, the hydrogen of solvated water molecules is connected through strong intermolecular $\mathrm{O}-\mathrm{H} \cdot$ $\cdots \mathrm{Cl}$ hydrogen-bonding interactions $(\mathrm{O}-\mathrm{H} \cdots \cdot \mathrm{Cl}: 2.43(11)$ $\AA ; 171(10)^{\circ}$ ) between coordinated chlorine atoms of two adjacent $\mathrm{Cu}_{2}$ dimers (Figure $\mathrm{S} 2$ ).

(b) $\left[\mathrm{Cu}_{2}\left(\mathrm{OH}_{2}\right)\left(\mathrm{ClO}_{4}\right) \mathrm{L}^{2}{ }_{2}\right]\left(\mathrm{ClO}_{4}\right)$ (3). A similar reaction of the hydrated salt $\mathrm{Cu}\left(\mathrm{ClO}_{4}\right)_{2} \cdot 6 \mathrm{H}_{2} \mathrm{O}$ with an equimolar quantity of the deprotonated ligand $\left[\mathrm{L}^{2}\right]^{-}$in methanol produced a cationic dicopper complex $\left[\mathrm{Cu}_{2}\left(\mathrm{OH}_{2}\right)\left(\mathrm{ClO}_{4}\right) \mathrm{L}^{2}{ }_{2}\right]-$ $\left(\mathrm{ClO}_{4}\right)(3)$ (yield, $\left.70 \%\right)$. The bonding pattern of the two anionic ligands in $\mathbf{3}$ is identical with that of $\mathbf{2}$; however, the geometry of $\mathbf{3}$ is different. While complex $\mathbf{2}$ is distorted trigonal bipyramid, complex $\mathbf{3}$, in contrast, is a distorted square pyramidal. ${ }^{14}$ The value of $\tau$ for $\mathrm{Cu}(1)$ is 0.33 and for $\mathrm{Cu}(2)$ is 0.37 . Figure 3 shows the ORTEP and atomnumbering scheme for $\mathbf{3}$, and its bond parameters are collected in Table 1. The tridentate coordination of one $\left[\mathrm{L}^{2}\right]^{-}$ and a pyridyl nitrogen atom of a second $\left[\mathrm{L}^{2}\right]^{-}$ligand, together with the oxygen atom of $\mathrm{H}_{2} \mathrm{O}$, completes five-coordination about $\mathrm{Cu}(1)$. The coordination mode of the organic ligand about $\mathrm{Cu}(2)$ is similar to that of $\mathrm{Cu}(1)$, with only the difference of a $\mathrm{ClO}_{4}$ coordination in place of $\mathrm{H}_{2} \mathrm{O}$ coordination. The three coordinating nitrogen atoms, viz. $\mathrm{N}(6), \mathrm{N}(8)$, and $\mathrm{N}(9)$, form a good plane, and $\mathrm{Cu}(1)$ sits above the plane by $0.2475(12) \AA$. Similarly, the second metal ion, $\mathrm{Cu}(2)$,

(14) Addison, A. W.; Rao, T. N.; Reedijk, J.; Rijn, J. V.; Verschoor, G. C. J. Chem. Soc., Dalton Trans. 1984, 1349.

(15) Orpen, A. G.; Brammer, L.; Allen, F. H.; Kennard, O.; Watson, D. G.; Taylor, R. J. Chem. Soc., Dalton Trans. 1989, 12, S1-S83.

(16) (a) Shi, X.; Zhu, G.; Wang, X.; Li, G.; Fang, Q.; Wu, G.; Tian, G.; Xue, M.; Zhao, X.; Wang, R.; Qiu, S. Cryst. Growth Des. 2005, 5, 207. (b) Castillo, O.; Luque, A.; Iglesias, S.; Vitoria, P.; Román, P. New. J. Chem. 2000, 24, 771.

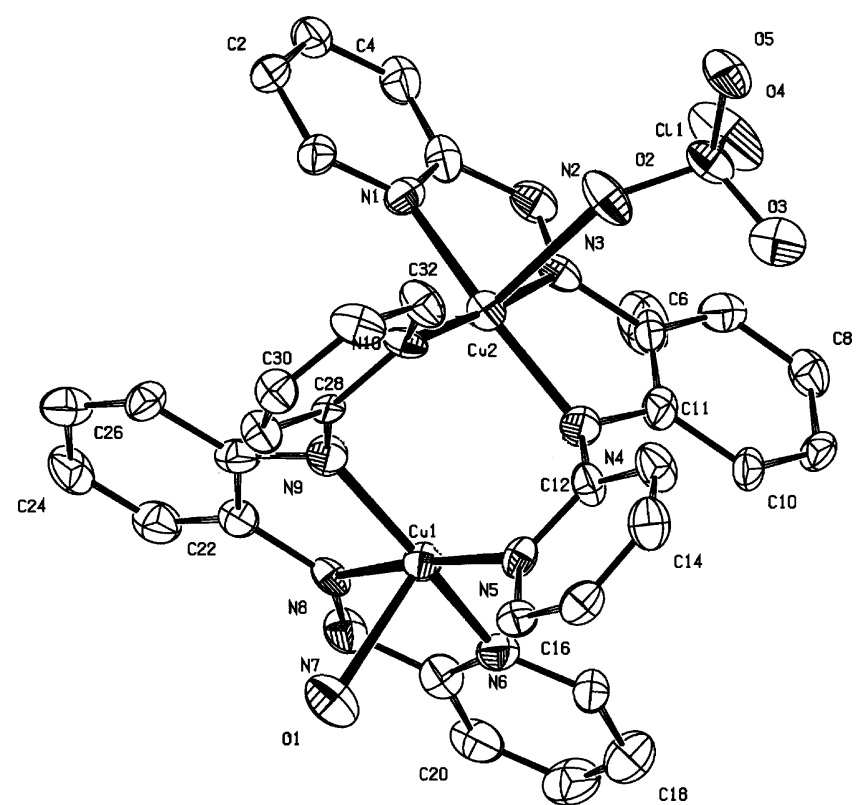

Figure 3. ORTEP and atom-numbering scheme for $\left[\mathrm{Cu}_{2}\left(\mathrm{OH}_{2}\right)\left(\mathrm{ClO}_{4}\right) \mathrm{L}_{2}^{2}\right]-$ $\left(\mathrm{ClO}_{4}\right)(3)$. Hydrogen atoms and uncoordinated perchlorate ion are omitted for clarity.

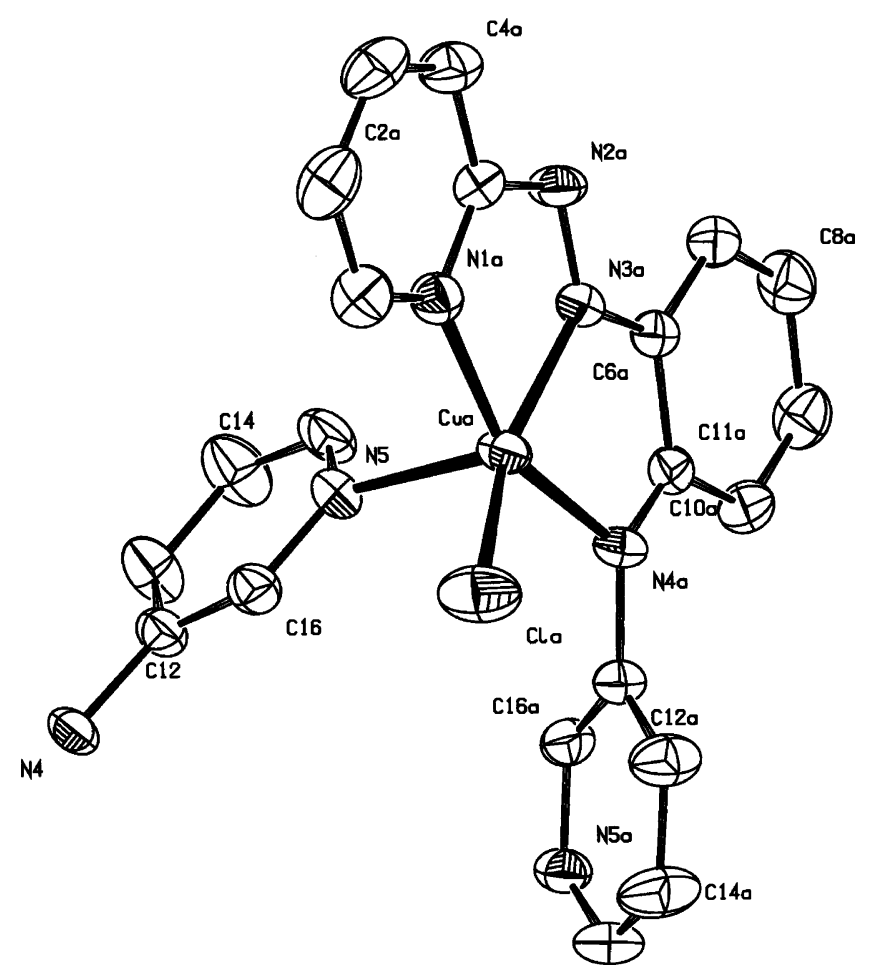

Figure 4. ORTEP and atom-numbering scheme for $\left[\mathrm{CuClL}^{3}\right]_{n}$ (4). Hydrogen atoms are omitted for clarity.

lies below the plane formed by three coordinated nitrogen atoms, viz. $\mathrm{N}(1), \mathrm{N}(3)$, and $\mathrm{N}(4)$, by $0.1802(12) \AA$. The nonbonded distance between the two copper atoms is 3.4207 $\AA$. There also exist two longer $\mathrm{Cu}{ }^{\cdots} \mathrm{N}$ contacts $[\mathrm{Cu}(1)-\mathrm{N}(10)$ $3.50037 \AA$ and $\mathrm{Cu}(2)-\mathrm{N}(5) 3.4925 \AA]$ as it is observed in the case of the compound $\mathbf{2}$. The molecule also contains one $\mathrm{CH}_{3} \mathrm{CN}$ as a solvent of crystallization.

(iii) Polynuclear Copper(II) Complex. The ligand $\mathrm{HL}^{3}$ in methanol reacted instantaneously with an aqueous solution of hydrated cupric chloride in the presence of triethylamine 

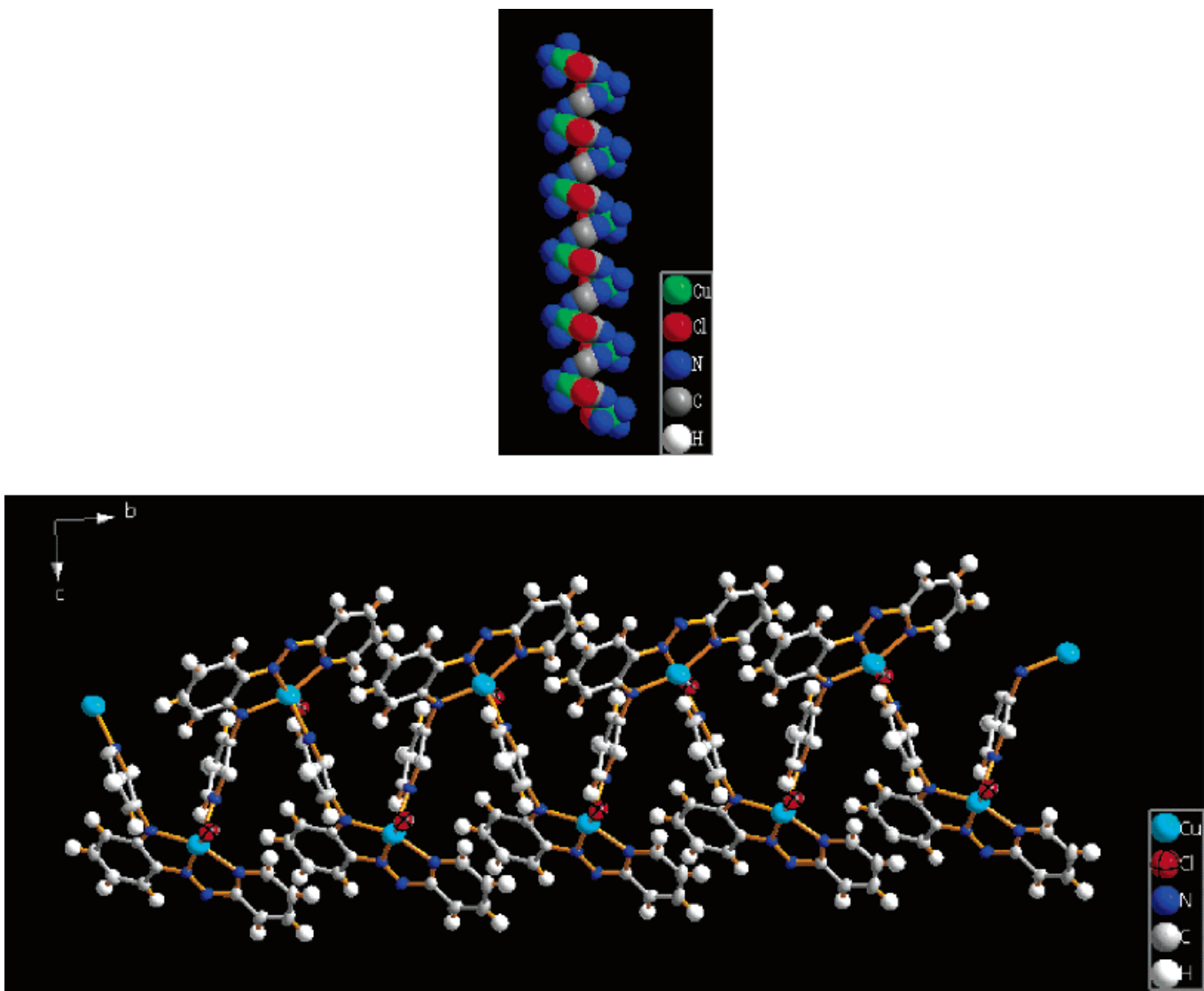

Figure 5. (a) Space-filling model of the zigzag chain of $\left[\mathrm{CuClL}^{3}\right]_{n}$ (4) producing a saw-tooth-like backbone. (b) Segmented ellipsoid view of the $1 \mathrm{D}$ chain of the copper(II) polymer.

to produce an insoluble dark green complex $\left[\mathrm{CuClL}^{3}\right]_{n}(\mathbf{4})$. $\mathrm{X}$-ray-quality crystals of it were grown by slow diffusion of an aqueous solution of $\mathrm{CuCl}_{2} \cdot 2 \mathrm{H}_{2} \mathrm{O}$ into a deprotonated methanolic solution of $\left[\mathrm{L}^{3}\right]^{-}$. A similar reaction of $\mathrm{Cu}-$ $\left(\mathrm{ClO}_{4}\right)_{2} \cdot 6 \mathrm{H}_{2} \mathrm{O}$ with $\left[\mathrm{L}^{3}\right]^{-}$also produced a very short-lived green solution, which turned brown quickly, and no pure compound could be isolated from the above mixture. Structural analysis of $\mathbf{4}$ reveals infinite 1D chain. Figure 4 shows its ORTEP along with atom numbering scheme, and the bond parameters are collected in Table 1. In this molecule each copper atom is surrounded in a pentacoordinated $\mathrm{N}_{4} \mathrm{Cl}$ environment. The geometry of each copper(II) ion may be described $^{14}$ as square pyramidal $(\tau=0.02)$. In complex 4 the three coordinating nitrogen atoms, viz. $\mathrm{N}(1 \mathrm{a}), \mathrm{N}(3 \mathrm{a})$, and $\mathrm{N}(4 \mathrm{a})$, form a good plane and $\mathrm{Cu}(1 \mathrm{a})$ sits above the plane by $0.1383(4) \AA$. Interestingly, the coordination mode of the deprotonated ligand, $\left[\mathrm{L}^{3}\right]^{-}$, is found to be different from that of its positional isomer $\left[\mathrm{L}^{2}\right]^{-}$and is perfectly suited for a metal-ligand extended network. The bending of the ligand and its coordination about the copper center results in a zigzag chain ${ }^{17}$ that adopts a saw-tooth-like structure (Figure $5)$. In this lattice, the polymeric network runs along the $b$ axis, where $\mathrm{Cu}(\mathrm{a})-\mathrm{N}(5)$ of the bridging pyridine distance is 2.205(3) A. Hence, the bridging pyridyl nitrogen of the next molecule interacts with the copper of the earlier molecule axially forming a 1D chain. There are two polymeric chains,

(17) Moulton, B.; Zaworotko, M. J. Chem. Rev. 2001, 101, 1629. which are mirror images. The interchain $\mathrm{Cu}{ }^{\cdots} \mathrm{Cu}$ distance across the bridging ligand is 7.0450(7) $\AA$.

B. Spectral Studies. The positive ion ESI mass spectra of the soluble complexes $\mathbf{1 - 3}$ were recorded in dichloromethane. The representative mononuclear copper complex 1a shows an intense peak at $\mathrm{m} / \mathrm{z}, 337 \mathrm{amu}$ which is assigned to $\left[\mathrm{M}_{\mathrm{c}}-\mathrm{X}\right]^{+}$, where $\mathrm{M}_{\mathrm{c}}$ and $\mathrm{X}$ represent the molecule and $\mathrm{Cl}^{-}$, respectively. Each of the two dinuclear copper(II) complexes, viz. 2 and $\mathbf{3}$, shows a peak at $\mathrm{m} / \mathrm{z} 711$ and 775 amu, respectively, due to $\left[2-\left(\mathrm{Cl}+\mathrm{H}_{2} \mathrm{O}\right)\right]^{+}$and $\left[\mathbf{3}-\left(\mathrm{ClO}_{4}\right.\right.$ $\left.\left.+\mathrm{H}_{2} \mathrm{O}\right)\right]^{+}$. In all the cases the experimental isotopic distributions for the above molecular ions corresponded to the simulated pattern. Each spectrum is associated with daughter peaks due to fragmentation. Thus, the ESIMS data provide evidence for the integrity of the complexes also in solution.

IR spectra of the copper(II) complexes show the presence of all characteristic bands $\mathrm{s}^{4,8}$ for the coordinated ligands with $v_{\mathrm{C}=\mathrm{N}}$ and $\nu_{\mathrm{N}=\mathrm{N}}$ appearing in the ranges 1590-1595 and $1305-1325 \mathrm{~cm}^{-1}$, respectively. Notably, complex 3 shows three peaks near $1100 \mathrm{~cm}^{-1}$ and one peak near $620 \mathrm{~cm}^{-1}$. Among these, two peaks are due to the coordinated ${ }^{18}$ perchlorate ion and one peak is due to uncoordinated perchlorate. While the complexes $\mathbf{1 - 3}$ are soluble in common organic solvents, complex $\mathbf{4}$, on the other hand, is insoluble. The solution electronic spectra of the complexes

(18) Thirumavalavan, L.; Akilan, P.; Kantaswamy, M.; Chinnakali, K.; Kumar, G. S.; Fun, H. K. Inorg. Chem. 2003, 42, 3308. 
1-3 dominated by a moderately intense ( $\epsilon$ : ca. 3600 for $\mathbf{1}$ and 12300 and $13100 \mathrm{M}^{-1} \mathrm{~cm}^{-1}$ for $\mathbf{2}$ and $\mathbf{3}$, respectively) and broad charge-transfer transition in the visible range $(700-650 \mathrm{~nm})$. In addition, these also show transitions in the UV-region, which are ascribed to intraligand charge transfer. The solid-state absorption spectrum of $\mathbf{4}$ shows a low-energy structured band near $700 \mathrm{~nm}$. Interestingly, the intensities of transitions for the dicopper complexes, $\mathbf{2}$ and $\mathbf{3}$, are much higher than those for the mononuclear copper complexes, 1. Such observations were noted ${ }^{19}$ before in diand polynuclear systems having a repetition of units that are responsible for the reference electronic transitions. Semiempirical EHMO calculations on the complex 2 using the CACAO program ${ }^{20}$ by Mealli and Proserpio indicated that while the HOMO is an admixture of metal and ligand orbitals, the LUMO is predominantly ligand orbitals. On the other hand, the HOMO for each of the complexes $\mathbf{1}, \mathbf{3}$, and 4 is predominantly ligand orbitals while the LUMO is a mixture of metal and ligand orbitals. Hence, the lowest energy transition in the present copper(II) complexes may be described as a $\pi-\pi^{*}$ transition, ${ }^{8}$ where the $\pi$-orbitals are either an admixture of metal and ligand orbitals or ligand orbitals.

C. Magnetic Studies. Room-temperature magnetic moments of the mononuclear copper(II) complexes $1 \mathbf{a}-\mathbf{c}$ fall in the range, $1.68-1.72 \mu_{\mathrm{B}}$ that are close to the spin-only value $1.73 \mu_{\mathrm{B}}$ for a single unpaired electron. Variabletemperature magnetic susceptibility data for the di- and polynuclear complexes 2-4 were measured at temperature ranging from 2.0 to $300 \mathrm{~K}$. The dinuclear complex $\mathbf{2}$ showed very weak antiferromagnetic behavior. The resulting plots of the $\chi_{\mathrm{M}}$ versus $T$ and the $\chi_{\mathrm{M}} T$ versus $T$ are submitted as Supporting Information (Figure S3). From the curve it is observed that the $\chi_{\mathrm{M}} T$ value is $0.91 \mathrm{~cm}^{3} \mathrm{~K} \mathrm{~mol}^{-1}$ at room temperature, which decreases gradually with lowering of temperature. The $\chi_{\mathrm{m}} T=0.91 \mathrm{~cm}^{3} \mathrm{~K} \mathrm{~mol}^{-1}$ at $300 \mathrm{~K}$ is higher than the spin-only value $\chi_{\mathrm{m}} T=0.75 \mathrm{~cm}^{3} \mathrm{~K} \mathrm{~mol}^{-1}$ for the uncorrelated two $\mathrm{Cu}^{\mathrm{II}}(S=1 / 2)$ with $g=2.00$. Such a high $\chi_{\mathrm{M}} T$ value has been reported ${ }^{21}$ for other dinuclear copper(II) complex such as $\left[\mathrm{Cu}_{2}(\mathrm{t} \text {-bupy })_{4}\left(\mathrm{~N}_{3}\right)_{2}\right]\left(\mathrm{ClO}_{4}\right)_{2}$, where t-bupy stands for 4-tert-butylpyridine. The temperature dependence of $\chi_{\mathrm{m}} T$ indicates that two $\mathrm{Cu}^{\mathrm{II}}$ ions are coupled antiferromagnetically ${ }^{22}$ through the bridging ligands. The susceptibility data were fitted by the following expression derived ${ }^{23}$ by Bleany and Bowers:

$$
\chi=\frac{2 N g^{2} \beta^{2}}{k T[3+\exp (-J / k T)]}
$$

Here $N$ is Avogadro's number, $\beta$ the Bohr magneton, and $k$

(19) Rillema, D. P.; Sahai, R.; Matthvews, P.; Edwarts, A. K.; Shaver, R. J.; Morgan, L. Inorg. Chem. 1990, 29, 167.

(20) Mealli, C.; Proserpio, D. M. J. Chem. Educ. 1990, 67, 399.

(21) Sikorav, S.; Bkouche-Waksman, I.; Khan, O. Inorg. Chem. 1984, 23, 490.

(22) (a) Castillo, O.; Luque, A.; Sertucha, J.; Román, P.; Lloret, F. Inorg. Chem. 2000, 39, 6142. (b) Girerd, J. J.; Khan, O.; Verdaguer, M. Inorg. Chem. 1980, 19, 274.

(23) Bleany, B.; Bowers, K. D. Proc. R. Soc. London, Ser. A 1952, 214 451.
Boltzman's constant. A good-fitting curve was obtained for the following parameters: $J=-1.04 \mathrm{~cm}^{-1} ; g=2.04$.

The resulting plot of the $\chi_{\mathrm{M}} T$ versus $T$ for $\mathbf{3}$ is submitted as Supporting Information (Figure S4). At room temperature $\chi_{\mathrm{M}} T$ is equal to $0.76 \mathrm{~cm}^{3} \mathrm{~K} \mathrm{~mol}^{-1}(300 \mathrm{~K})$. This value at room temperature is consistent with the spin-only value $\chi_{\mathrm{M}} T$ $=0.75 \mathrm{~cm}^{3} \mathrm{~K} \mathrm{~mol}^{-1}$ for the uncorrelated two $\mathrm{Cu}^{\mathrm{II}}(S=1 / 2)$ with $g=2.00$, and $\chi_{\mathrm{M}} T$ is almost constant until $100 \mathrm{~K}$. On further cooling, $\chi_{\mathrm{M}} T$ increases rapidly and reaches a maximum $\left(0.95 \mathrm{~cm}^{3} \mathrm{~K} \mathrm{~mol}^{-1}\right)$ at $5.0 \mathrm{~K}$, after which it decreases slightly to $0.90 \mathrm{~cm}^{3} \mathrm{~K} \mathrm{~mol}^{-1}$ at $2 \mathrm{~K}$. This curve is as expected for a dominant ferromagnetic coupling with weak intermolecular antiferromagnetic interactions and/or zero-field splitting of the triplet ground state which would account for the decrease of $\chi_{\mathrm{M}} T$ at $5 \mathrm{~K}$. The $\chi_{\mathrm{M}} T$ data for temperature range from 2 to $300 \mathrm{~K}$ were fitted by the modified Bleany and Bowers expression: ${ }^{23}$

$$
\chi=\frac{2 N g^{2} \beta^{2}}{k(T-\Theta)[3+\exp (-J / k T)]}
$$

A good-fitting curve was obtained for the following parameters: $J=9.88 \mathrm{~cm}^{-1} ; g=2.01 ; \Theta=-0.24 \mathrm{~K}$. The small positive $J$ value indicates a weak ferromagnetic ${ }^{24}$ coupling between the two copper(II) ions.

The resulting plot of the $\chi_{\mathrm{M}} T$ versus $T$ for $\mathbf{4}$ is submitted as Supporting Information (Figure S5). The room-temperature $\chi_{\mathrm{M}} T$ is equal to $0.76 \mathrm{~cm}^{3} \mathrm{~K} \mathrm{~mol}^{-1}(300 \mathrm{~K})$, which is consistent with the spin-only value $\chi_{\mathrm{M}} T=0.75 \mathrm{~cm}^{3} \mathrm{~K} \mathrm{~mol}^{-1}$ for the uncorrelated two $\mathrm{Cu}^{\mathrm{II}}(S=1 / 2)$ with $g=2.00$, and $\chi_{\mathrm{M}} T$ decreases slowly until $20 \mathrm{~K}$ and then decreases rapidly due to weak antiferromagnetic coupling of $\mathrm{Cu}$ ions. The room-temperature magnetic moment of the polycrystalline powder of complex 4 showed an experimental effective magnetic moment $\left(\mu_{\exp }\right)$ of $1.80 \mu_{\mathrm{B}}$, which is slightly higher than the spin-only magnetic moment for copper(II) ion (1.73 $\left.\mu_{\mathrm{B}}\right)$. The molar magnetic susceptibility data for temperature range from 2 to $300 \mathrm{~K}$ were fitted by Bonner and Fisher's model, ${ }^{25}$ and the best-fitted parameters obtained were $J=$ $-1.31 \mathrm{~cm}^{-1}$ and $g=2.09$.

The room-temperature EPR spectrum of each of the mononuclear complexes $\mathbf{1 a}-\mathbf{c}$ in dichloromethane solution exhibits a four-line spectrum with hyperfine coupling constant $(A)$ of $75-80 \mathrm{G}$ and $g_{\mathrm{av}}=2.10$. In contrast, the solutions of the dinuclear complexes $\mathbf{2}$ and $\mathbf{3}$ both are EPR inactive at room temperature. However, the frozen solution (dichloromethane-toluene, 1:1) of $\mathbf{2}$ shows a broad axial spectrum (2: $\left.g_{\mathrm{II}}, 2.03 ; A_{\mathrm{II}}, 83 \mathrm{G} ; g_{\perp}, 2.00\right)$ with ill-defined hyperfine components of the $g_{\text {II }}$ signals. A very broad spectrum centered at $g=2.01-2.04$ is observed for the frozen solution of compound $\mathbf{3}$. Compound $\mathbf{4}$ is insoluble, and hence, its solution spectrum could not be recorded. It exhibits an axial spectrum $\left(g_{\mathrm{II}}, 2.10 ; g_{-}, 2.07\right)$ in the solid state, but no hyperfine component was observed. Broadening

(24) (a) Reddy, P. A. M.; Nethaji, M.; Chakravarty, A. R. Eur. J. Inorg. Chem. 2003 2318. (b) Fitzgerald, W.; Foley, J.; McSweeney, D.; Ray, N.; Sheahan, D.; Tyagi, S. J. Chem. Soc., Dalton Trans. 1982, 1117. (25) Kahn, O. Molecular Magnetism; VCH: New York, 1993; p 252. 
Das et al.

of the EPR spectra in magnetically coupled systems is documented $^{18}$ in the literature. However, the extent of interactions in the present complexes is weak as evidenced by the cryomagnetic data for the above complexes. Very weak magnetic interactions in the present complexes may be ascribed to unfavorable overlaps of magnetic orbitals for the distorted complexes. ${ }^{26}$ Furthermore, we note that the magnitudes of separation between the copper centers are also considerably high.

D. Redox and Catalytic Activity of Complex 3. Redox behavior of the soluble copper(II) complexes $\mathbf{1 - 3}$ was studied by cyclic voltammetry in dichloromethane solvent using a platinum working electrode. The complexes $\mathbf{1}$ and $\mathbf{2}$ display multiple irreversible and quasireversible ill-natured responses, which are not considered further. Complex $\mathbf{3}$, however, displays two closely spaced one-electron reversible responses at +0.06 and $-0.05 \mathrm{~V}$. The separation between the two-reduction processes is small, and differential pulse voltammetry indeed identifies two successive steps. Constantpotential electrolysis of $\mathbf{3}$ was performed at $-0.4 \mathrm{~V}$, which confirmed an overall two-electron transfer for the above response. The two-redox processes are assigned as follows:

$$
\mathrm{Cu}^{\mathrm{II}} \mathrm{Cu}^{\mathrm{II}} \rightleftharpoons \mathrm{Cu}^{\mathrm{II}} \mathrm{Cu}^{\mathrm{I}} \rightleftharpoons \mathrm{Cu}^{\mathrm{I}} \mathrm{Cu}^{\mathrm{I}}
$$

The above processes are electrochemically reversible; the $\mathrm{Cu}_{2}{ }_{2}$ (green) regenerates $\mathrm{Cu}_{2}{ }_{2}$ (sky blue) almost quantitatively upon electrolysis at $0.35 \mathrm{~V}$. The reference ligand has a unique combination of hard as well as soft donor sites ${ }^{4}$ and is known to stabilize variable valence states of different metal ions. Furthermore, the lability of the fifth coordinating ligands in $\mathbf{3}$ is believed to be a key factor for the electrochemical reversibility. The voltammogram of $\mathbf{3}$ in dichloromethane is displayed in Figure 6, and the visible range spectra of the starting complex 3 and the electrogenarated $\mathrm{Cu}_{2}{ }^{\mathrm{I}}$ complex $\left([3]^{2-}\right)$ are shown as an inset of Figure 6.

Electrochemical reversibility of complex $\mathbf{3}$ persuaded us to examine its catalytic properties. Compound $\mathbf{3}$ reacts ${ }^{27}$ with L-ascorbic acid $\left(\mathrm{H}_{2} \mathrm{~A}\right)$ in aqueous methanol instantaneously to form a brownish-violet solution presumably due to the formation of copper(I) species. The color of the solution is stable in an inert atmosphere but regenerates the parent complex 3 quantitatively upon exposure to air. The above catalytic reaction is followed spectrophotometrically using an air-saturated solvent mixture. The catalytic cycle is most effective up to $\mathrm{H}_{2} \mathrm{~A} / \mathbf{3}$ molar ratio of $20: 1$ with quantitative regeneration of $\mathbf{3}$ (Figure 7), but complete regeneration of $\mathbf{3}$ is not be achieved at higher concentrations of $\mathrm{H}_{2} \mathrm{~A}$. For example, for a molar ratio of $30: 1,53 \%$ of $\mathbf{3}$ is regenerated after $7 \mathrm{~h}$. When the concentration of $\mathrm{H}_{2} \mathrm{~A}$ exceeds 50 times that of $\mathbf{3}$, its catalytic activity is completely lost. The overall rates of regeneration of the parent complex $\mathbf{3}$ are measured with $\mathrm{H}_{2} \mathrm{~A} / \mathbf{3}$ molar ratio of $10: 1,15: 1$, and $20: 1$ and the observed rates are $5.75,4.79$, and $2.87 \mathrm{M}^{-1} \mathrm{~s}^{-1}$, respectively.

(26) Mikuriya, M.; Okawa, H.; Kida, S. Bull. Chem. Soc. Jpn. 1982, 55, 1086.

(27) (a) Santra, B. K.; Reddy, P. A. N.; Nethaji, M.; Chakravarty, A. Inorg. Chem. 2002, 41, 1328. (b) Taquikhan, M. M.; Martell, A. E. J. Am. Chem. Soc. 1967, 89, 6.

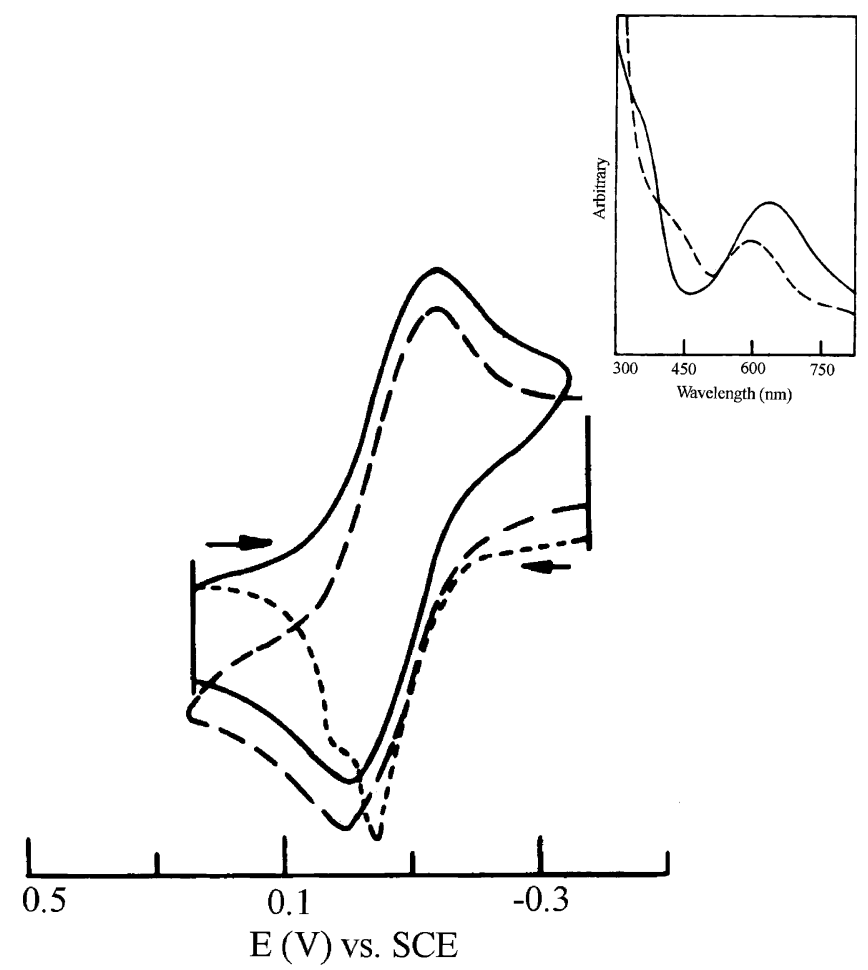

Figure 6. Voltammograms of $\left[\mathrm{Cu}_{2}\left(\mathrm{OH}_{2}\right)\left(\mathrm{ClO}_{4}\right) \mathrm{L}^{2}{ }_{2}\right]\left(\mathrm{ClO}_{4}\right)(3)$ in dichloromethane (0.1 M TBAP): cyclic voltammogram $(--)$; differential pulse voltammetry (---); cyclic voltammogram of electrogenerated $[3]^{2-}(-)$. Inset: Visible range spectra of (i) $\left[\mathrm{Cu}_{2}\left(\mathrm{OH}_{2}\right)\left(\mathrm{ClO}_{4}\right) \mathrm{L}^{2}{ }_{2}\right]\left(\mathrm{ClO}_{4}\right)(3)(-)$ and (ii) electrogenerated $[\mathbf{3}]^{2-}(---)$.

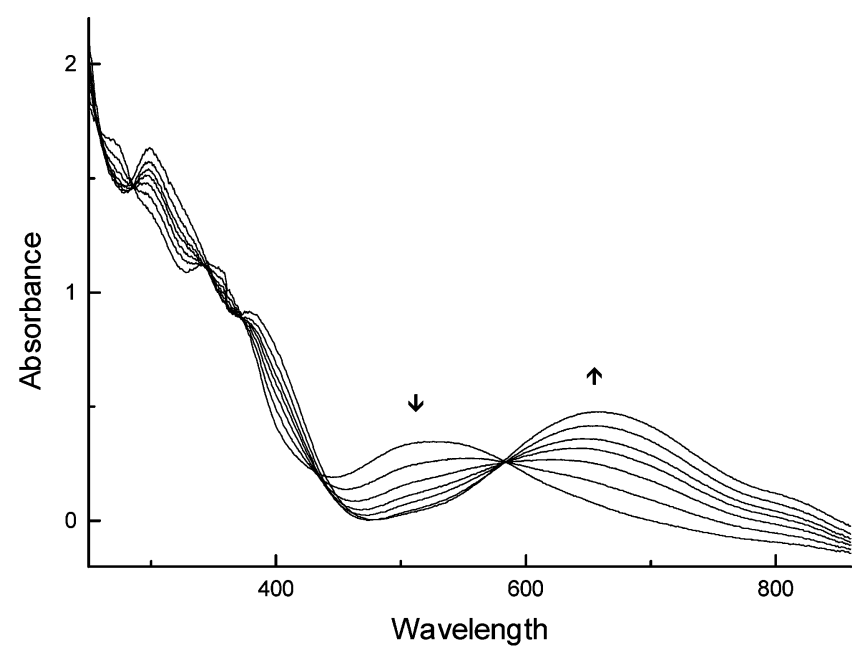

Figure 7. Time-dependence spectra of $\left[\mathrm{Cu}_{2}\left(\mathrm{OH}_{2}\right)\left(\mathrm{ClO}_{4}\right) \mathrm{L}_{2}^{2}\right]\left(\mathrm{ClO}_{4}\right)(3)$ at a molar ratio $\mathrm{H}_{2} \mathrm{~A} / \mathbf{3}$ of $20: 1$ in the air-saturated methanol-water solvent.

In contrast, complexes $\mathbf{1}$ and $\mathbf{2}$ both react with $\mathrm{H}_{2} \mathrm{~A}$ irreversibly to produce brown solutions of unknown compositions via the transient violet intermediates. The above catalytic process involving 3 consists of several steps that primarily include reduction of $\mathbf{3}$ by $\mathrm{L}$-ascorbic acid and reoxidation of copper(I) species by aerial oxygen.$^{28}$ Catalytic activity of copper(II) complexes toward oxidation ${ }^{29}$ of potential bioreductant L-ascorbic acid is of interest for the construction of possible models for copper enzymes.

(28) Scarpa. M.; Vianello, F.; Signor, L.; Zennaro, L.; Rigo, A. Inorg. Chem. 1996, 35, 5201.

(29) Davies, M. B. Polyhedron 1992, 11, 285. 
Table 2. Crystallographic Data

\begin{tabular}{|c|c|c|c|c|}
\hline param & 1c & 2 & 3 & 4 \\
\hline empirical formula & $\mathrm{C}_{18} \mathrm{H}_{15} \mathrm{ClSN}_{4} \mathrm{Cu}$ & $\mathrm{C}_{32} \mathrm{H}_{26} \mathrm{Cl}_{2} \mathrm{~N}_{10} \mathrm{Cu}_{2} \mathrm{O}$ & $\mathrm{C}_{34} \mathrm{H}_{29} \mathrm{Cl}_{2} \mathrm{~N}_{11} \mathrm{Cu}_{2} \mathrm{O}_{9}$ & $\mathrm{C}_{16} \mathrm{H}_{12} \mathrm{ClN}_{5} \mathrm{Cu}$ \\
\hline molecular mass & 418.39 & 764.61 & 933.66 & 373.30 \\
\hline cryst syst & monoclinic & orthorhombic & monoclinic & monoclinic \\
\hline space group & $C 2 / c$ & $F d d 2$ & $\mathrm{P} 2{ }_{1} / c$ & $P 2_{1} / c$ \\
\hline$a(\AA)$ & $27.2036(11)$ & $28.6584(5)$ & $10.5476(2)$ & $7.7002(5)$ \\
\hline$b(\AA)$ & $9.0209(4)$ & $11.7238(2)$ & $23.3966(3)$ & $7.8855(5)$ \\
\hline$c(\AA)$ & $15.4178(6)$ & $18.0082(3)$ & $15.1012(2)$ & $24.6440(16)$ \\
\hline$\alpha(\operatorname{deg})$ & 90 & 90 & 90 & 90 \\
\hline$\beta$ (deg) & $112.2120(10)$ & 90 & $94.3235(6)$ & $95.929(2)$ \\
\hline$\gamma(\mathrm{deg})$ & 90 & 90 & 90 & 90 \\
\hline$V\left(\AA^{3}\right)$ & $3502.8(3)$ & $6050.49(18)$ & $3716.04(10)$ & $1488.38(17)$ \\
\hline$Z$ & 8 & 8 & 4 & 4 \\
\hline$D_{\text {calcd }}\left(\mathrm{Mg} / \mathrm{m}^{3}\right)$ & 1.58 & 1.679 & 1.669 & 1.666 \\
\hline cryst dimens $\left(\mathrm{mm}^{3}\right)$ & $0.40 \times 0.35 \times 0.12$ & $0.20 \times 0.20 \times 0.1$ & $0.40 \times 0.20 \times 0.08$ & $0.40 \times 0.10 \times 0.02$ \\
\hline$\theta$ range for data collcn (deg) & $2.40-27.50$ & $2.19-27.50$ & $1.61-25.00$ & $1.66-27.50$ \\
\hline wavelength $(\AA)$ & 0.71073 & 0.71073 & 0.71073 & 0.71073 \\
\hline reflens colled & 14334 & 18155 & 20139 & 14423 \\
\hline unique reflcns & 4022 & 3372 & 6535 & 3416 \\
\hline \multirow[t]{2}{*}{ final $\mathrm{R}$ indices $(I>2 \sigma(I))$} & $\mathrm{R} 1=0.0328$ & $\mathrm{R} 1=0.0445$ & $\mathrm{R} 1=0.1159$ & $\mathrm{R} 1=0.0580$ \\
\hline & $\mathrm{wR}_{2}=0.0886$ & $w_{2}=0.1019$ & $\mathrm{wR}_{2}=0.2911$ & $\mathrm{wR}_{2}=0.1185$ \\
\hline
\end{tabular}

E. Conclusion. In this work we have successfully demonstrated how rational design of a ligand system can bring about mononuclear to polynuclear transition. In the present cupric complexes, while the noncovalent hydrogen-bonding interactions were observed in mono- and dinuclear copper systems, a 1D zigzag framework, through covalent interactions, was resulted in the polynuclear system. We note here that there has been an upsurge in research for the construction of new metal organic frameworks (MOF's) through the combination of suitable ligands and metal ions. Our work in this direction using the ligand $\mathrm{HL}^{3}$ and the $\mathrm{d}^{10}$-metal ions is in progress. Furthermore, redox behavior of the $\mathrm{Cu}_{2}$ complex $\mathbf{3}$ is noteworthy. It catalyzes aerial oxidation of L-ascorbic acid, which may be useful in extracting further insights into biochemical $\mathrm{Cu}_{2}$-based $\mathrm{O}_{2}$ activation processes.

\section{Experimental Section}

Materials. All solvents and chemicals used for synthesis were of analytical grade. The ligands $\mathrm{HL}^{1}-\mathrm{HL}^{3}$ were prepared by following the reported $\mathrm{d}^{4 \mathrm{a}, 8 \mathrm{~b}}$ procedure using the appropriate aromatic monoamines.

Caution! Perchlorate salts of metal complexes can be explosive. Although no detonation tendencies have been observed, care is advised and handling of only small quantities recommended.

Physical Measurements. A JASCO V-570 spectrometer was used to record electronic spectra. The IR spectrums were recorded with a Perkin-Elmer 783 spectrophotometer. A Perkin-Elmer 240C elemental analyzer was used to collect microanalytical data $(\mathrm{C}, \mathrm{H}$, $\mathrm{N})$. Electrochemical measurements were performed under a dry nitrogen atmosphere at $298 \mathrm{~K}$ on a PAR model 370-4 electrochemistry system as described before. ${ }^{30}$ The potentials reported herein are referenced to the saturated calomel electrode (SCE) and are uncorrected for junction contribution. The value for the ferrocenium-ferrocene couple under our experimental conditions is 0.40 $\mathrm{V}$. Tetrabutylammonium perchlorate was used as the supporting electrolyte. ESI mass spectra were recorded on a micro mass Q-TOF mass spectrometer (serial no. YA 263). Room-temperature magnetic moments were carried out with a PAR 155 vibrating-sample

(30) Goswami, S.; Mukerjee, R.; Chakravorty, A. Inorg. Chem. 1983, 22, 2825. magnetometer fitted with a walker scientific L75FBAL magnet. Variable-temperature, direct current (dc) magnetic susceptibility data on polycrystalline dicopper samples, viz. $\mathbf{2}$ and $\mathbf{3}$ (ca. $25 \mathrm{mg}$ each), were collected using a Quantum Design MPMS5-XL SQUID susceptometer in the temperature range of $2-300 \mathrm{~K}$ and in an applied magnetic field of $10000 \mathrm{Oe}$. The diamagnetic correction was estimated from Pascal's constants and was subtracted from the experimental susceptibility to give the molar paramagnetic susceptibility. The room-temperature and low-temperature (77 K) EPR measurements were made with a Varian 109C E-line X-band spectrometer fitted with a flat cell and equipped with quartz Dewar flask. Spectra were calibrated against the spectrum of DPPH ( $g=2.0037)$. The catalytic activity of the complex 3 toward aerial oxidation of Lascorbic acid was studied in a $10^{-3} \mathrm{M}$ air-saturated methanolwater $(9: 1)$ solvent mixture. The reaction was followed spectrophotometrically by choosing the strongest absorbance at $650 \mathrm{~nm}$ and monitoring the increase in the absorbance at this wavelength as a function of time.

Synthesis of Compounds. A. Mononuclear Copper(II) Complexes. [CuClL ${ }^{1 \mathrm{a}}$ ] (1a). The methanolic solution $(25 \mathrm{~mL})$ of the ligand $\mathrm{HL}^{1 \mathrm{a}}(100 \mathrm{mg}, 0.365 \mathrm{mmol})$ was deprotonated by addition of a few drops of dilute triethylamine solution. To this solution a methanolic solution of $\mathrm{CuCl}_{2} \cdot 2 \mathrm{H}_{2} \mathrm{O}(65 \mathrm{mg}, 0.365 \mathrm{mmol})$ was added, and the whole mixture was stirred for $1 \mathrm{~h}$ at room temperature. The color of the resultant solution changed from red to dark green. The resultant mixture was filtered, and the solvent was evaporated under vacuum. The green compound, thus obtained, was crystallized from a dichloromethane-hexane solvent mixture. Yield: $80 \%$. Anal. Calcd for $\mathrm{C}_{17} \mathrm{H}_{13} \mathrm{~N}_{4} \mathrm{ClCu}$ : C, 54.8; H, 3.5; $\mathrm{N}$, 15.0. Found: $\mathrm{C}, 54.9 ; \mathrm{H}, 3.4 ; \mathrm{N}, 15.0$. IR ( $\mathrm{KBr}$ disk, $\left.v, \mathrm{~cm}^{-1}\right)$ : $1595(\mathrm{C}=\mathrm{N}), 1320(\mathrm{~N}=\mathrm{N}) . \mathrm{UV}-$ visible spectrum (dichloromethane) $\left[\lambda_{\max }, \mathrm{nm}\left(\epsilon, \mathrm{M}^{-1} \mathrm{~cm}^{-1}\right)\right]: 705$ (3570), 420 (3360), 310 (14 135), 275 (15 900), 205 (56 410). $\mu_{\text {eff }}(298 \mathrm{~K}): 1.68 \mu_{\mathrm{B}}$. ESIMS: $m / z, 337,[\mathrm{M}-\mathrm{Cl}]^{+}$.

The other substituted complexes were prepared similarly by using the appropriate ligands, $\mathrm{HL}^{1 \mathrm{~b}}-\mathrm{HL}^{1 \mathrm{c}}$. Their yields and characterization data are as follows:

[CuClL ${ }^{1 b}$ ] (1b). Yield: 80\%. Anal. Calcd for $\mathrm{C}_{18} \mathrm{H}_{15} \mathrm{~N}_{4} \mathrm{ClCu}$ : C, 56.0; H, 3.9; N, 14.5. Found: C, 56.1; H, 3.9; N, 14.6. IR ( $\mathrm{KBr}$ disk, $\left.v, \mathrm{~cm}^{-1}\right)$ : $1595(\mathrm{C}=\mathrm{N}), 1330(\mathrm{~N}=\mathrm{N}) . \mathrm{UV}-$ visible spectrum (dichloromethane) $\left[\lambda_{\max }, \mathrm{nm}\left(\epsilon, \mathrm{M}^{-1} \mathrm{~cm}^{-1}\right)\right]: 715$ (3470), 435 (4680), 315 (16 580), 280 (20 615), 205 (65 840). $\mu_{\text {eff }}(298 \mathrm{~K}): 1.72$ $\mu_{\mathrm{B}}$. ESIMS: $m / z, 351,[\mathrm{M}-\mathrm{Cl}]^{+}$. 
[CuClL ${ }^{1 c}$ ] (1c). Yield: 75\%. Anal. Calcd for $\mathrm{C}_{18} \mathrm{H}_{15} \mathrm{~N}_{4} \mathrm{ClSCu}$ : C, 51.6; H, 3.6; N, 13.4. Found: C, 51.9; H, 3.4; N, 13.6. IR ( $\mathrm{KBr}$ disk, $\left.v, \mathrm{~cm}^{-1}\right): 1595(\mathrm{C}=\mathrm{N}), 1305(\mathrm{~N}=\mathrm{N}) . \mathrm{UV}-$ visible spectrum (dichloromethane) $\left[\lambda_{\max }, \mathrm{nm}\left(\epsilon, \mathrm{M}^{-1} \mathrm{~cm}^{-1}\right)\right]: 720$ (3200), 450 (3790), 320 (14 690), 260 (16 110), 210 (56 550). $\mu_{\mathrm{eff}}(298 \mathrm{~K}): 1.70$ $\mu_{\mathrm{B}}$. ESIMS: $m / z, 383,[\mathrm{M}-\mathrm{Cl}]^{+}$.

B. Dinuclear Copper(II) Complexes. (i) $\left[\mathrm{Cu}_{2} \mathrm{Cl}_{2} \mathrm{~L}^{2}{ }_{2}\right] \cdot \mathrm{H}_{2} \mathrm{O}$ (2). The ligand $\mathrm{HL}^{2}$ (100 mg, $0.365 \mathrm{mmol}$ ) was dissolved in $25 \mathrm{~mL}$ of methanol and was deprotonated by the addition of a few drops of dilute triethylamine. To this solution a methanolic solution of $\mathrm{CuCl}_{2}$. $2 \mathrm{H}_{2} \mathrm{O}$ (64 mg, $0.365 \mathrm{mmol}$ ) was added, and the whole solution was stirred for $1 \mathrm{~h}$ at room temperature. The color of the solution changed from orange to sky blue. The resultant mixture was filtered, and the solvent was evaporated under vacuum. A dark crystalline compound was obtained through slow evaporation of a concentrated methanolic solution of the compound. Yield: $75 \%$. Anal. Calcd for $\mathrm{C}_{32} \mathrm{H}_{24} \mathrm{~N}_{10} \mathrm{Cl}_{2} \mathrm{Cu}_{2} \cdot \mathrm{H}_{2} \mathrm{O}$ : C, 50.2; H, 3.4; N, 18.3. Found: C, 50.5; H, 3.4; N, 18.1. IR (KBr disk, $\left.v, \mathrm{~cm}^{-1}\right): 1600(\mathrm{C}=\mathrm{N}), 1315$ $(\mathrm{N}=\mathrm{N})$. UV-visible spectrum (dichloromethane) $\left[\lambda_{\max }, \mathrm{nm}\left(\epsilon, \mathrm{M}^{-1}\right.\right.$ $\mathrm{cm}^{-1}$ )]: 635 (12 300), 360 (25 000), 300 (34 450), 235 (32 415). ESIMS: $m / z, 711,\left[\mathrm{M}-\left(\mathrm{Cl}+\mathrm{H}_{2} \mathrm{O}\right)\right]^{+}$.

(ii) $\left[\mathrm{Cu}_{2}\left(\mathrm{OH}_{2}\right)\left(\mathrm{ClO}_{4}\right) \mathrm{L}_{2}^{2}\right]\left(\mathrm{ClO}_{4}\right)(3)$. This was prepared similarly by reacting appropriate quantities of $\mathrm{Cu}\left(\mathrm{ClO}_{4}\right)_{2} \cdot 6 \mathrm{H}_{2} \mathrm{O}(135 \mathrm{mg}$, $0.365 \mathrm{mmol}$ ) and the deprotonated ligand $\left[\mathrm{L}^{2}\right]^{-}$as described above. Crystals were grown by slow diffusion of toluene into acetonitrile solution of the compound. Yield: $75 \%$. Anal. Calcd for $\mathrm{C}_{32} \mathrm{H}_{29} \mathrm{~N}_{11^{-}}$ $\mathrm{Cl}_{2} \mathrm{O}_{9} \mathrm{Cu}_{2}: \mathrm{C}, 43.7 ; \mathrm{H}, 3.1 ; \mathrm{N}, 16.5$. Found: $\mathrm{C}, 43.6 ; \mathrm{H}, 3.4 ; \mathrm{N}$, 16.3. IR ( $\mathrm{KBr}$ disk, $\left.v, \mathrm{~cm}^{-1}\right): 1600(\mathrm{C}=\mathrm{N}), 1310(\mathrm{~N}=\mathrm{N}) 1100$, $620\left(\mathrm{ClO}_{4}^{-}\right) . \mathrm{UV}-$ visible spectrum (dichloromethane) $\left[\lambda_{\max }, \mathrm{nm}\right.$ $\left.\left(\epsilon, \mathrm{M}^{-1} \mathrm{~cm}^{-1}\right)\right]$ : 655 (13 000), 380 (18 985), 305 (32 320), 245 (41 185). ESIMS: $m / z$ 775, $\left[\mathrm{M}-\left(\mathrm{ClO}_{4}+\mathrm{H}_{2} \mathrm{O}\right)\right]^{+}$.

C. Polynuclear Copper(II) Complex. $\left[\mathrm{CuClL}^{3}\right]_{n}$ (4). In a long neck crystal tube, an aqueous solution $(5 \mathrm{~mL})$ containing $\mathrm{CuCl}_{2}$. $2 \mathrm{H}_{2} \mathrm{O}(65 \mathrm{mg}, 0.365 \mathrm{mmol})$, a blank methanol solvent $(2 \mathrm{~mL})$, and the deprotonated methanolic solution of $\left[\mathrm{L}^{3}\right]^{-}(100 \mathrm{mg}, 0.65 \mathrm{mmol})$ were added gradually. Between the water and methanol solvent layer, a green ring was formed. The tube was stoppered and left to stand at room temperature. Slow diffusion between the two solutions afforded dark green crystals of $\mathbf{4}$ within 2 weeks. Yield: $70 \%$. Anal. Calcd for $\mathrm{C}_{16} \mathrm{H}_{12} \mathrm{~N}_{5} \mathrm{ClCu}$ : C, 51.4; H, 3.2; N, 18.8. Found: C, 51.6; $\mathrm{H}, 3.0 ; \mathrm{N}, 18.9$. IR (KBr disk, $\left.v, \mathrm{~cm}^{-1}\right): 1595(\mathrm{C}=\mathrm{N}), 1300(\mathrm{~N}=$ N). UV-visible spectrum (solid; $\lambda_{\max }, \mathrm{nm}$ ): 700, 425, 365, 345, 320, 250 .

Crystallography. Crystallographic data for the compounds 1c and $\mathbf{2 - 4}$ are collected in Table 2. Specific details are given below.

[CuClL $\left.{ }^{1 c}\right](\mathbf{1 c})$. The suitable X-ray-quality crystals $(0.40 \times 0.35$ $\left.\times 0.12 \mathrm{~mm}^{3}\right)$ of $\left[\mathrm{CuClL}^{1 \mathrm{c}}\right](\mathbf{1 c})$ were obtained by slow diffusion of hexane into dichloromethane solution of the compound. The data were collected on a Bruker SMART diffractometer equipped with
Mo K $\alpha$ radiation $(\lambda=0.71073 \AA)$ and were corrected for Lorentzpolarization effects. A total of 14334 reflections were collected out of which 4022 were unique $\left(R_{\text {int }}=0.0229\right)$ and were used in subsequent analysis.

$\left[\mathrm{Cu}_{\mathbf{2}} \mathbf{C l}_{2} \mathbf{L}^{2}{ }_{2}\right] \cdot \mathbf{H}_{2} \mathbf{O}$ (2). The suitable $\mathrm{X}$-ray-quality crystals $(0.20$ $\left.\times 0.20 \times 0.10 \mathrm{~mm}^{3}\right)$ of $\left[\mathrm{Cu}_{2} \mathrm{Cl}_{2} \mathrm{~L}_{2}^{2}\right] \cdot \mathrm{H}_{2} \mathrm{O}(2)$ were obtained by slow evaporation of a concentrated methanol solution of the compound. The data were collected as noted above. A total of 18155 reflections were collected out of which 3372 were unique $\left(R_{\text {int }}=0.0473\right)$ and were used in subsequent analysis.

$\left[\mathrm{Cu}_{2}\left(\mathrm{OH}_{2}\right)\left(\mathrm{ClO}_{4}\right) \mathrm{L}_{2}^{2}\right]\left(\mathrm{ClO}_{4}\right)$ (3). The suitable X-ray-quality crystals $\left(0.40 \times 0.20 \times 0.08 \mathrm{~mm}^{3}\right)$ of $\left[\mathrm{Cu}_{2}\left(\mathrm{OH}_{2}\right)\left(\mathrm{ClO}_{4}\right) \mathrm{L}_{2}{ }_{2}\right]\left(\mathrm{ClO}_{4}\right)$ (3) were obtained by slow diffusion of toluene into acetonitrile solution of the compound. The data were collected as noted above. A total of 20139 reflections were collected out of which 6535 were unique $\left(\mathrm{R}_{\mathrm{int}}=0.0487\right)$ and were used in subsequent analysis. Complex 3 has two unreasonable peaks. One peak has $7.26 \mathrm{e}^{-} / \AA^{3}$ near the atom of $\mathrm{Cu}(2)$ and $\mathrm{N}(4)(1.037,1.059 \AA)$; the other peak has $6.36 \mathrm{e}^{-} / \AA^{3}$ near the atoms of $\mathrm{Cu}(1)$ and $\mathrm{N}(9)(1.417,0.704 \AA)$. So the structure has a higher $\mathrm{R}_{1}$ value.

$\left[\mathrm{CuClL}^{3}\right]_{n} \mathbf{( 4 )}$. The suitable X-ray-quality crystals $(0.40 \times 0.10$ $\left.\times 0.02 \mathrm{~mm}^{3}\right)$ of $\left[\mathrm{CuClL}^{3}\right]_{n}(4)$ were obtained by slow diffusion of aqueous solution of $\mathrm{CuCl}_{2} \cdot 2 \mathrm{H}_{2} \mathrm{O}$ into the deprotonated methanolic solution of the ligand, $\left[\mathrm{L}^{3}\right]^{-}$. The data were collected as noted above. A total of 14423 reflections were collected out of which 3416 were unique $\left(\mathrm{R}_{\mathrm{int}}=0.0468\right)$ and were used in subsequent analysis.

All structures were solved by employing the SHELXS 97 program package ${ }^{31}$ and refined by full-matrix least squares based on $F^{2}$ (SHELXL-97). ${ }^{32}$

Acknowledgment. Financial support received from the Department of Science and Technology, New Delhi, and the Council of Scientific and Industrial Research, New Delhi, is gratefully acknowledged. We are thankful to Prof. R. Mukherjee, IIT, Kanpur, India, for his help in studying the crystal packing in the present complexes. S.D. also thanks the Council of Scientific and Industrial Research for his fellowship. J.K. thanks the MOST (NRL program) of Korea. We are also grateful to the reviewers for their suggestions.

Supporting Information Available: X-ray crystallographic data in cif format; figures of $1 \mathrm{c}$ and $2 ; \chi_{\mathrm{M}}$ vs $T$ plots for various compounds. This material is available free of charge via the Internet at http://pubs.acs.org.

\section{IC051029C}

(31) Sheldrick, G. M. Acta Crystallogr., Sect. A 1990, 46, 467.

(32) Sheldrick, G. M. SHELXL 97. Program for the refinement of crystal structures; University of Göttingen: Göttingen, Germany, 1997. 